\title{
Vitamin C may exert variable effects on viability and proliferation of HeLa cells exhibiting high and low chromosomal instability
}

\author{
Aastha Sindhwani ${ }^{B, C}$, Sasikala Muthusammy ${ }^{B, C}$, Alka Bhatia ${ }^{A, C-F}$ \\ Department of Experimental Medicine \& Biotechnology, Postgraduate Institute of Medical Education \& Research, Chandigarh, India \\ A - research concept and design; B - collection and/or assembly of data; C - data analysis and interpretation; \\ $D$ - writing the article; $E$ - critical revision of the article; $F$ - final approval of the article
}

Address for correspondence

Alka Bhatia

E-mail:alkabhatia@ymail.com

\section{Funding sources}

The in-house grant provided by the Postgraduate Institute of Medical Education \& Research, Chandigarh, India.

Conflict of interest

None declared

Received on February 2, 2017

Reviewed on March 24, 2017

Accepted on September 7, 2017

Published online on August 29, 2018

\begin{abstract}
Background. Chromosomal instability (CIN), defined as abnormality in chromosome structure or number, is the hallmark of malignancies. The role of vitamin C in cancer treatment is controversial and its effect on CIN is still an open field of research. In this work, we tried to study the effect of high-dose L-ascorbic acid (L-AA) on CIN-induced (CIN ${ }_{\text {hi }}=C I N$ high) and non-CIN-induced (CIN $\left.\right|_{10}=C I N$ low) cervical cancer cells.
\end{abstract}

Objectives. The aim of this study was to explore the effect of high-dose L-AA on CIN in the cervical cancer cell line (HeLa) cells.

Material and methods. The HeLa cells ( $\left(\mathrm{IN}_{\text {hi }}\right.$ and $\left(\mathrm{IN}_{\mathrm{I}_{0}}\right)$ were treated with 2 doses $(5 \mathrm{mM}$ and $8 \mathrm{mM})$ of L-AA for $24 \mathrm{~h}$ and $48 \mathrm{~h}$. They were then analyzed by micronucleus (MN) scoring, eell ploidy and flow cytometry, the latter regarding $\mathrm{yH} 2 \mathrm{AX}$ expression. Cell viability was assessed by the methylthiazol tetrazolium (MTT) and Annexin V assays.

Results. Treatment of $C \mathrm{~N}_{\mathrm{hi}}$ cells with L-AA led to a decrease in MN score (colchicine - $71.5 \pm 4.95,67.5 \pm 0.71$; L-AA $(5 \mathrm{mM})-49 \pm 7.07,46.5 \pm 4.95 ; \mathrm{L}-\mathrm{AA}(8 \mathrm{mM})-42 \pm 9.89,41 \pm 1.41$, at $24 \mathrm{~h}$ and $48 \mathrm{~h}$, respectively; $\mathrm{p}<0.05)$. Treatment of $\mathrm{CIN} \mathrm{N}_{10}$ cells with L-AA resulted in increased MN score $(5 \mathrm{mM}-45 \pm 7.07,36 \pm 4.24$; $8 \mathrm{mM}-34.5 \pm 4.95,31 \pm 1.41$, at $24 \mathrm{~h}$ and $48 \mathrm{~h}$, respectively; control $-15.5 \pm 0.71,12.5 \pm 0.71 ; p<0.05)$ and reduction in cancer cell viability (control $-100 \%$; L-AA (5 mM) - 76.32\% $\pm 28.73,72.74 \% \pm 20.30$; L-AA $(8 \mathrm{mM})-66.14 \% \pm 19.13,66.99 \% \pm 19.99$, at $24 \mathrm{~h}$ and $48 \mathrm{~h}$, respectively; $\mathrm{p}<0.05)$. The expression of $\mathrm{H} 2 \mathrm{AX}$ was high in both groups at $48 \mathrm{~h}$ (mean $\mathrm{CIN}_{\mathrm{hi}}=19.42 \%, \mathrm{CN}_{10}=21.14 \%$; control $=1.19 \%$ and $1.58 \%$, respectively) with the $8 \mathrm{mM}$ dose of L-AA.

Conclusions. L-ascorbic acid was found to have a differential effect on $\mathrm{CIN}_{\mathrm{hi}}$ and $\mathrm{CIN}_{\mathrm{l}} \mathrm{H}$ HeLa cells, which may be due to differences in oxidation status of these 2 categories.

Key words: cancer, vitamin C, chromosomal instability

Cite as

Sindhwani A, Muthusammy S, Bhatia A. Vitamin C may exert variable effects on viability and proliferation of HeLa cells exhibiting high and low chromosomal instability. Adv Clin Exp Med. 2019;28(1):19-24. doi:10.17219/acem/76870

DOI

10.17219/acem/76870

Copyright

Copyright by Author(s)

This is an article distributed under the terms of the

Creative Commons Attribution Non-Commercial License

(http://creativecommons.org/licenses/by-nc-nd/4.0/) 


\section{Introduction}

Chromosomal instability (CIN) is the defining feature of most malignancies. Many environmental factors, including dietary influences, may contribute to CIN. ${ }^{1}$ L-ascorbic acid (L-AA), commonly known as vitamin C, is a water-soluble vitamin with pro- and antioxidant roles. The role of L-AA in cancer is controversial, with studies variably reporting its anti- and pro-cancer effects. ${ }^{2-4}$ Although various mechanisms have been proposed for its anti-cancer effects, the exact mode of action of L-AA on cancer cells is not well understood. Yun et al. in their work on the effect of a high dose of vitamin $C$ in colorectal cancer demonstrated its cytotoxicity to KRAS and BRAF mutated cancer cells, owing to the uptake and reduction of its oxidized form, dehydroascorbate. ${ }^{5}$ Doskey et al. in their work on pancreatic cancer cell lines, demonstrated that cytotoxicity of ascorbate to cancer cells was due to the generation of $\mathrm{H}_{2} \mathrm{O}_{2}$, which cancer cells fail to clear because of low catalase activity. ${ }^{4}$ More recently, vitamin $\mathrm{C}$ has been found to be effective in targeting cancer stem cells. ${ }^{6}$ Although it has been suggested that it may selectively inflict
DNA damage in cancer cells, there is no conclusive data on the effect of L-AA on DNA damage and CIN in cancer. We carried out this study with the aim of evaluating the effect of high-dose L-AA on CIN in the cervical cancer cell line (HeLa) cells.

\section{Material and methods}

The HeLa was used in the study to evaluate the effect of high-dose L-AA on cancer cells. The HeLa cells were obtained from a commercial source (National Centre for Cell Science, Pune, India) and maintained in the RPMI (Roswell Park Memorial Institute) 1640 formulation with 10\% fetal calf serum (FCS) at $37^{\circ} \mathrm{C}$ in an atmosphere of $5 \%$ carbon dioxide $\left(\mathrm{CO}_{2}\right)$. The cells were plated in 6 -well culture plates for incubation with drugs and all the experiments were carried out thrice. For the induction of CIN, the cells were treated with metaphase-arresting drug colchicine $(0.2-200 \mu \mathrm{g} / \mathrm{mL})$ for $24 \mathrm{~h}$ and $48 \mathrm{~h}$, respectively. Chromosomal instability in the cells was assessed by staining them with Giemsa stain and counting the number of micronuclei

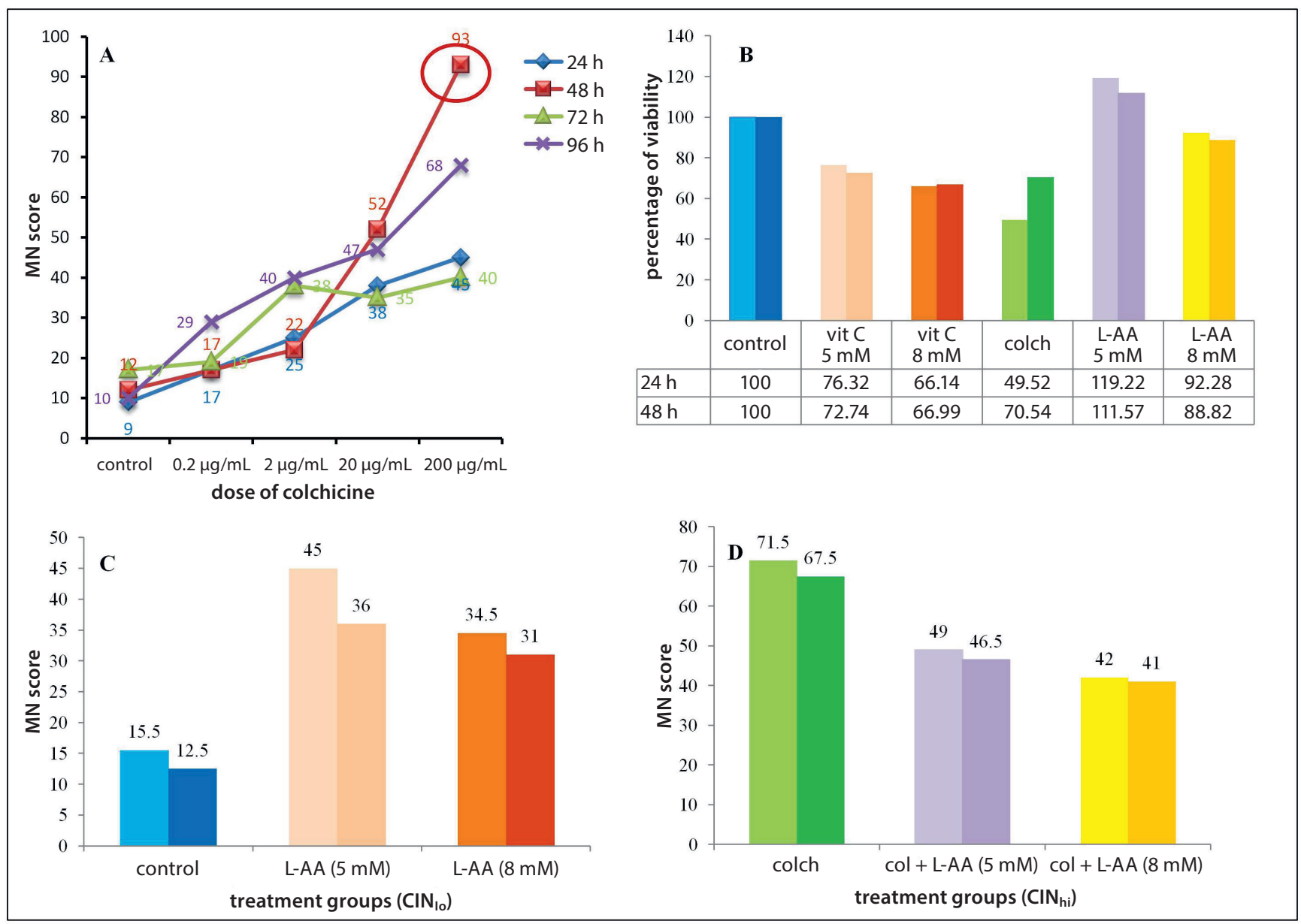

Fig. 1. A - micronucleus (MN) score at different concentrations of colchicine. Note that the highest score was found with $200 \mu \mathrm{g} / \mathrm{mL}$ at $48 \mathrm{~h}$ (encircled). This concentration was therefore chosen to induce chromosomal instability (CIN) in our study; B - percentage of viability of the HeLa cells in different treatment groups at $24 \mathrm{~h}$ and $48 \mathrm{~h}$ (double bars). Note the decreased viability in non-CIN-induced (CIN $\mathrm{N}_{\mathrm{l}}$ ) cells upon treatment with L-ascorbic acid (L-AA). However, in CIN-induced (CIN $\left.N_{h i}\right)$ cells, no decrease was observed; $C, D-M N$ score in $C I N_{l o}$ and $C I N_{h i}$ cells, respectively. Note that there was a higher score in the former group as compared to the control, whereas in the latter group, the score was found to be lower when compared to colchicine treatment alone 
(MN) present per 1,000 cells under a light microscope. The dose of colchicine causing maximum CIN was chosen for the induction of CIN in further experiments. Both CIN-induced $\left(\mathrm{CIN}_{\mathrm{hi}}=\mathrm{CIN}\right.$ high $)$ and non-CIN-induced $\left(\mathrm{CIN}_{\text {lo }}=\mathrm{CIN}\right.$ low $)$ cells were then treated with 2 doses of L-AA ( $5 \mathrm{mM}$ and $8 \mathrm{mM}$ ) for 2 time periods of $24 \mathrm{~h}$ and $48 \mathrm{~h}$, respectively. At the end of the incubation period, the effect on parameters, like cell viability (methylthiazol tetrazolium (MTT) assay), apoptosis (Annexin V assay) and CIN MN counting, and the expression of DNA doublestrand breaks (DSB) marker $(\gamma \mathrm{H} 2 \mathrm{AX})$, was assessed.

\section{Results}

\section{Micronucleus score after treatment with colchicine}

Upon treatment with colchicine, the HeLa cells showed a variable number of MN (9-93/1,000 cells). However,

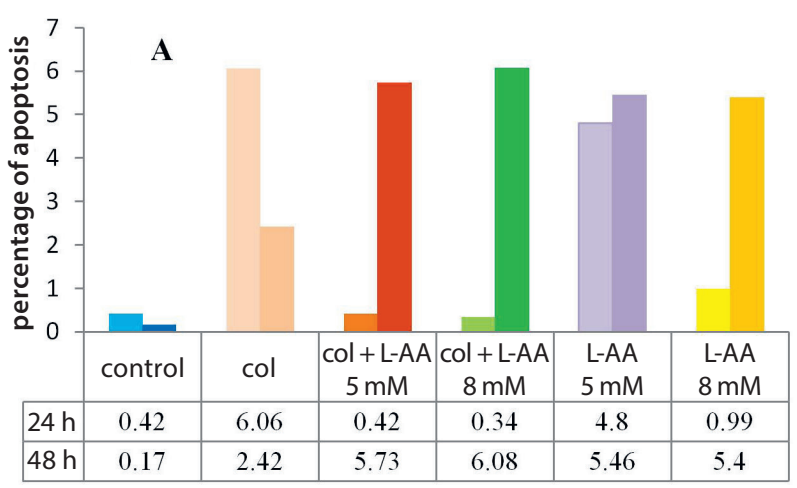

the maximum number of $\mathrm{MN}$ (93/1,000 cells) was noted with $200 \mu \mathrm{g} / \mathrm{mL}$ at $48 \mathrm{~h}$. Therefore, the latter dose and duration was used for the induction of CIN in HeLa cells (Fig. 1A).

\section{Effect of L-ascorbic acid on proliferation and viability of $\mathrm{CIN}_{\mathrm{hi}}$ and $\mathrm{CIN}_{\mathrm{lo}}$ HeLa cells}

A reduction in proliferation and viability of $\mathrm{CIN}_{\text {lo }}$ cells was noted upon treatment with L-AA at both doses $(5 \mathrm{mM}-76.32 \% \pm 28.73 \%, 72.74 \% \pm 20.30 \%$; $8 \mathrm{mM}-66.14 \% \pm 19.13 \%, 66.99 \% \pm 19.99 \%$, at $24 \mathrm{~h}$ and $48 \mathrm{~h}$, respectively; $\mathrm{p}<0.05$, paired t-test). However, the reduction in viability was totally absent or only minimal in $\mathrm{CIN}_{\mathrm{hi}}$ cells (Fig. 1B).

\section{Effect of different doses of L-ascorbic acid on micronucleus scoring in $\mathrm{CIN}_{\text {hi }}$ and $\mathrm{CIN}_{\text {lo }}$ HeLa cells}

Treatment of $\mathrm{CIN}_{\mathrm{hi}}$ HeLa cells with L-AA led to a significant decrease in $\mathrm{MN}$ score at both durations (colchicine alone - 71.5 $\pm 4.95,67.5 \pm 0.71 ; \mathrm{CIN}_{\mathrm{hi}}(5 \mathrm{mM})-49.00 \pm 7.07$, $46.5 \pm 4.95 ; \mathrm{CIN}_{\mathrm{hi}}(8 \mathrm{mM})-42 \pm 9.89,41 \pm 1.41$, at $24 \mathrm{~h}$ and $48 \mathrm{~h}$, respectively; $\mathrm{p}<0.055$, paired t-test) (Fig. 1C). However, in $\mathrm{CIN}_{\mathrm{lo}}$ cells, the MN score upon treatment with vitamin $\mathrm{C}(5 \mathrm{mM}=45 \pm 7.07,36 \pm 4.24 ; 8 \mathrm{mM}=34.5 \pm 4.95$, $31 \pm 1.41$ at $24 \mathrm{~h}$ and $48 \mathrm{~h}$, respectively) was found to be significantly higher than in the untreated control ( $15.5 \pm 0.71$, $12.5 \pm 0.71$, p-value $<0.05$, paired t-test) at both durations of treatment (Fig. 1D).

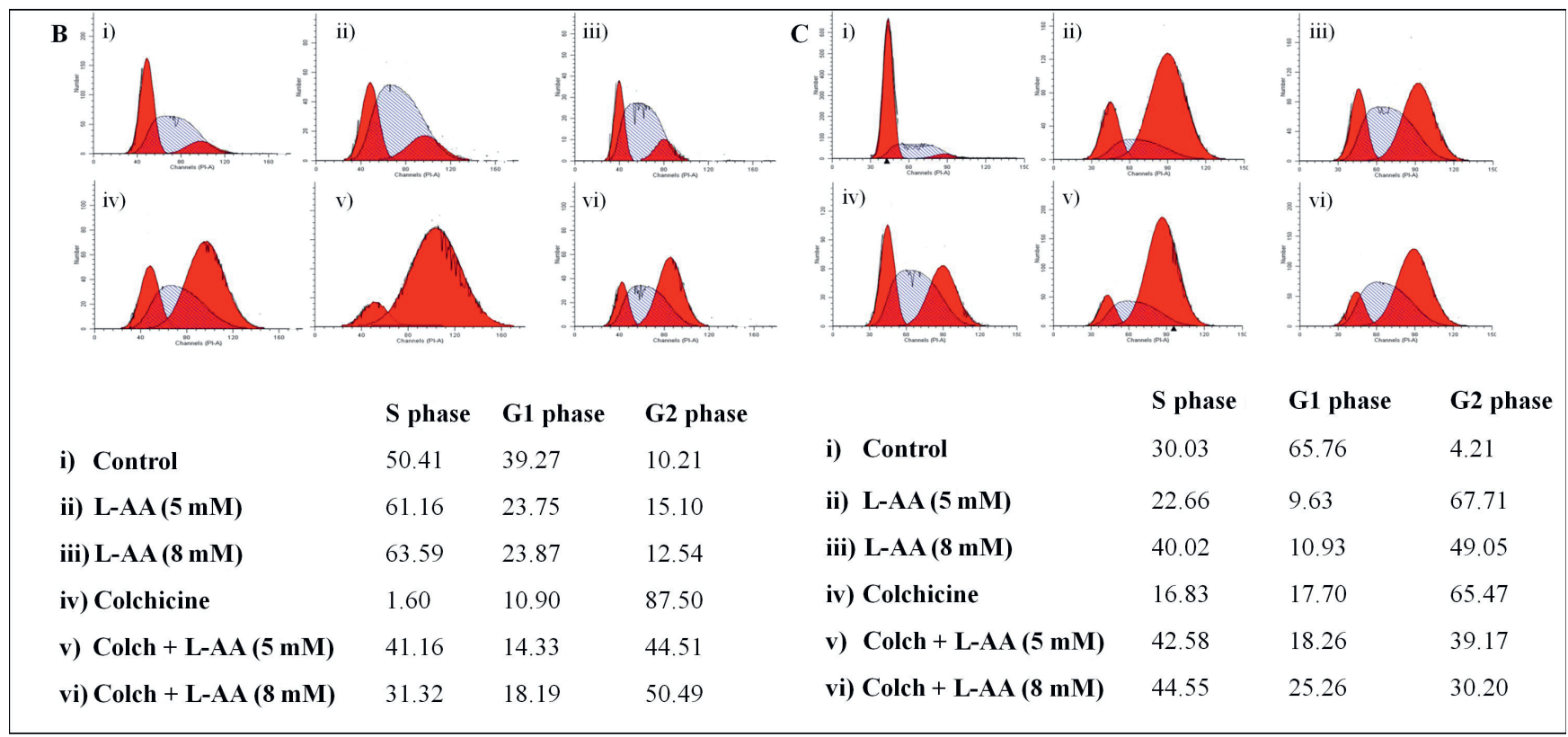

Fig. 2. A - percentage of apoptosis in HeLa cells upon treatment with various drugs. No significant increase was observed; $B$, $C$ - distribution of cells in different phases of the cell cycle in different treatment groups: i) control; ii) L-ascorbic acid (L-AA) 5 mM; iii) L-AA 8 mM; iv) colchicine; v) colchicine + LAA $5 \mathrm{mM}$; vi) colchicine + L-AA $8 \mathrm{mM}$, at $24 \mathrm{~h}$ and $48 \mathrm{~h}$, respectively. Note the G2/M arrest caused by colchicine at both durations, and the presence of the majority of cells in the $S$ and G2/M phases in L-AA-treated groups with or without colchicine 


\section{Effect of L-ascorbic acid on apoptogenicity of $\mathrm{CIN}_{\mathrm{hi}}$ and $\mathrm{CIN}_{\mathrm{lo}}$ cells}

Annexin V assay showed no significant increase in the percentage of apoptotic cells with any of the drugs used in our experiments (Fig. 2A).

\section{Effect of L-ascorbic acid on the cell cycle of $\mathrm{CIN}_{\mathrm{hi}}$ and $\mathrm{CIN}_{\mathrm{lo}}$ HeLa cells}

Treatment with colchicine resulted in cell cycle arrest at the $\mathrm{G} 2 / \mathrm{M}$ phase $(87.50 \%$ and $65.47 \%$ at $24 \mathrm{~h}$ and $48 \mathrm{~h}$, respectively). When the cells $\mathrm{CIN}_{\mathrm{hi}}$ were treated with both doses of L-AA, the majority of cells were found to be distributed in the $S$ and G2/M phases of the cell cycle at both treatment durations. The cells $\mathrm{CIN}_{\mathrm{lo}}$ were found to be mainly distributed in the $S$ phase at 24 and the G2/M phase at $48 \mathrm{~h}$, respectively (Fig. 2B,C).

\section{Effect of L-ascorbic acid on the expression of DNA damage response marker $\mathrm{\gamma H} 2 \mathrm{AX}$ in HeLa cells}

An increase in the percentage of $\gamma \mathrm{H} 2 \mathrm{AX}$-positive cells was noted in both $\mathrm{CIN}_{\mathrm{hi}}$ and $\mathrm{CIN}_{\mathrm{lo}}$ cells, particularly after treatment with $8 \mathrm{mM}$ L-AA (mean $\gamma \mathrm{H} 2 \mathrm{AX}$ expression $-19.42 \%, 21.14 \%$; control $-1.19 \%, 1.58 \%$, respectively) after
$48 \mathrm{~h}$ of treatment (Fig. 3). However, there was no significant change in the expression of $\gamma \mathrm{H} 2 \mathrm{AX}$ in colchicine-treated cells.

\section{Discussion}

Cancers are heterogeneous in nature. Some degree of numerical and structural defect in chromosomes, termed as CIN, is present in most tumors. The current literature has emphasized the presence of populations of more differentiated and more aggressive cells in cancers, the latter harboring more genetic defects and being less susceptible to therapy. Therefore, the agents being tested for targeting cancer should be investigated in the light of their effects on different populations of cells present in cancer. ${ }^{1}$

Many past studies have stressed the beneficial effect of high-dose vitamin $C$ intake in cancer. Many papers have described the inhibitory effect of millimolar concentrations of L-AA in vitro. However, many other studies have reported contrary results. ${ }^{2-4,7}$ In view of the controversial literature on the effect of L-AA on cancer cells, we undertook the present work to investigate its effect on HeLa cells harboring CIN.

To induce a higher degree of CIN, we treated the HeLa cells with a high dose of colchicine. ${ }^{8}$ The 2 types of cells, when treated with vitamin $\mathrm{C}$, showed paradoxical results.

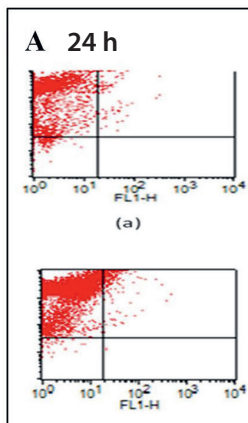

(d)

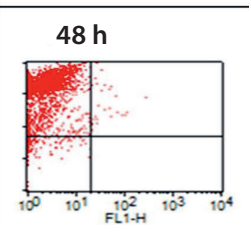

(a)

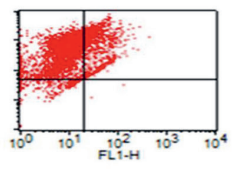

(d)
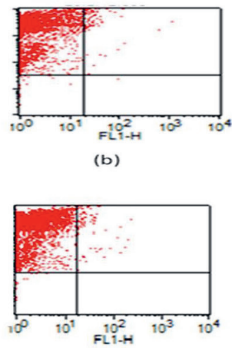

(e)

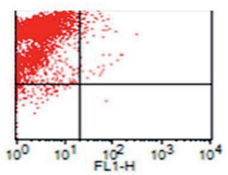

(b)

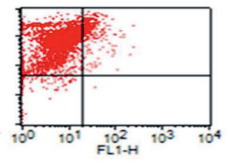

(e)
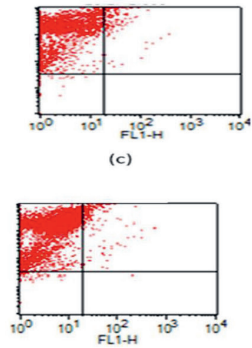

(f)

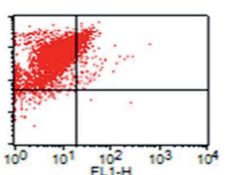

(c)

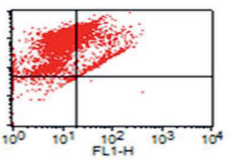

(f)

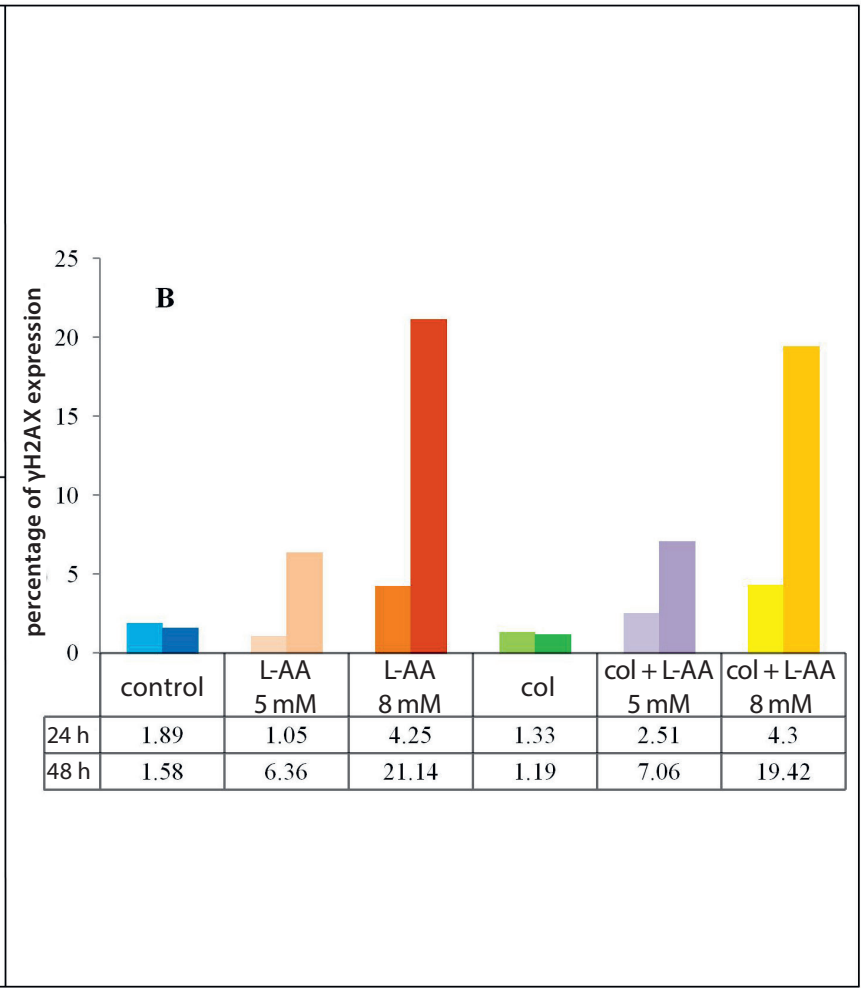

Fig. 3. A - the expression of $\gamma H 2 A X$ in HeLa cells in different treatment groups: (a) control; (b) L-ascorbic acid (L-AA) 5 mM; (c) L-AA 8 mM; (d) colchicine; (e) colchicine + L-AA $5 \mathrm{mM}$; (f) colchicine + L-AA $8 \mathrm{mM}$, at $24 \mathrm{~h}$ and $48 \mathrm{~h}$, respectively; $\mathrm{B}$ - bar diagram comparing the $\mathrm{YH} 2 \mathrm{AX}$ expression in different groups. Note a significant increase in expression at the $8 \mathrm{mM}$ dose of L-AA, particularly at $48 \mathrm{~h}$, in both low chromosomal instability $\left(\mathrm{CIN}_{\mathrm{lo}}\right)$ and high $\mathrm{CIN}\left(\mathrm{CIN} \mathrm{N}_{\mathrm{hi}}\right)$ groups, indicating the induction of DNA damage repair response with vitamin C 


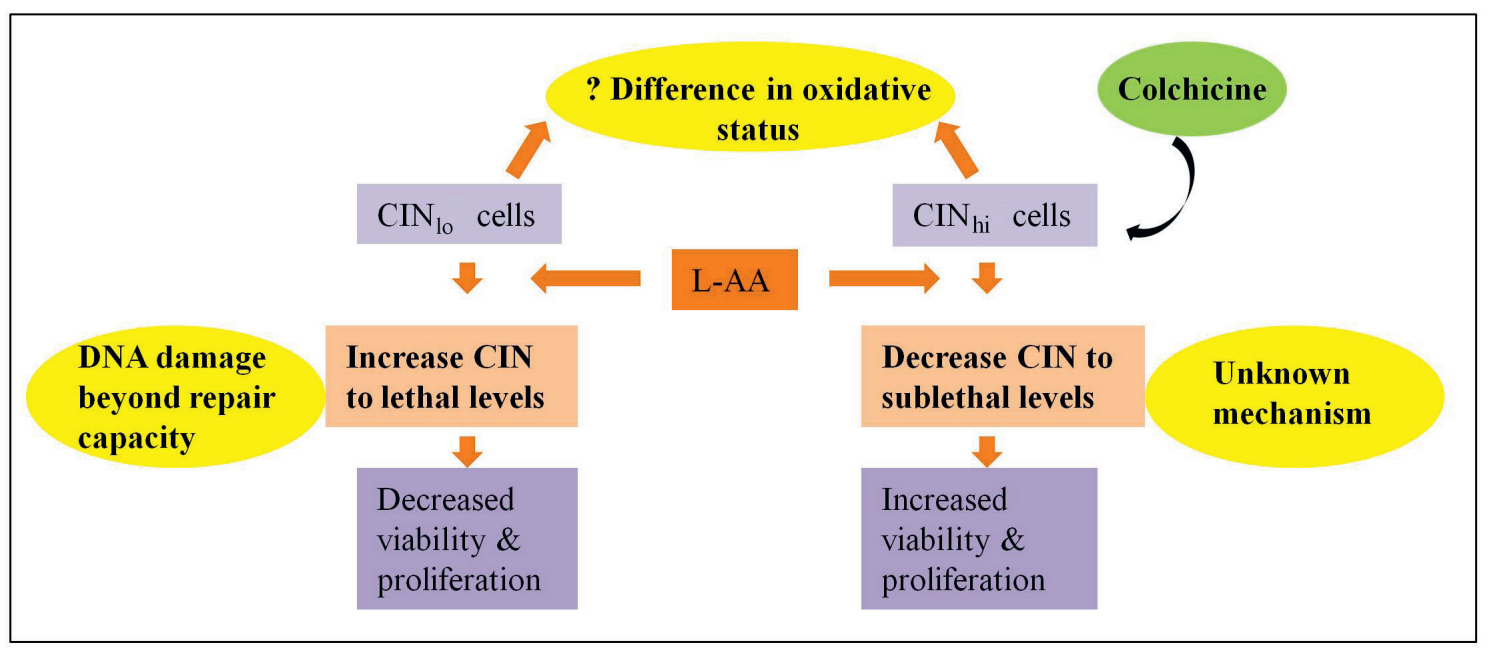

Fig. 4. Possible explanation for the differential effect of vitamin C in high chromosomal instability (CIN $\left.\mathrm{N}_{i}\right)$ and low CIN (CIN $\mathrm{I}_{\mathrm{o}}$ ) HeLa cells: a hypothesis

L-AA - L-ascorbic acid.

Vitamin $\mathrm{C}$ was found to enhance $\mathrm{CIN}$ in $\mathrm{CIN}_{\text {lo }}$ cells, at the same time decreasing their viability and proliferation. However, in $\mathrm{CIN}_{\text {hi }}$ cells, vitamin $\mathrm{C}$ was observed to reduce $\mathrm{CIN}$, at the same time increasing their viability and proliferation. We hypothesize that this may be due to cell death being triggered by L-AA via the induction of DNA damage beyond the repair capacity of the cancer cells in the former case. In the latter case $\left(\mathrm{CIN}_{\mathrm{hi}}\right.$ cells), treatment with L-AA was probably decreasing CIN to sublethal levels by unknown mechanisms, allowing the more aggressive population of cells to proliferate (Fig. 4). Some of the previous studies carried out on lymphocytes have also demonstrated the genotoxic potential of L-AA, especially in the presence of oxidizing agents like $\mathrm{H}_{2} \mathrm{O}_{2}$ or heavy metals like iron. The induction of single-strand breaks in the presence of oxidative stress was suggested as the mechanism behind the toxicity described above. Other studies have shown the protective effect of vitamin $\mathrm{C}$ on cisplatin-induced chromosome aberrations in lymphocytes in cancer patients. ${ }^{9,10}$ Interestingly, a study carried out on the HeLa cells by Azqueta et al. did not show any effect of L-AA on DNA strand break or base excision repair; however, the concentration used in their study was much lower (up to $200 \mu \mathrm{M}$ ) than that used by us. ${ }^{11}$ High-dose vitamin $C$ has also been proposed to cause increased DNA damage via the generation of reactive oxygen species (ROS) in gene-mutated cancer cells. ${ }^{5}$

Chromosomal instability is a double-edged sword. Up to a certain threshold, it is believed to increase cell proliferation; however, beyond that threshold, it is known to cause cell death. ${ }^{12}$ The results of our study, together with an increase in the expression of DNA damage response marker $\gamma \mathrm{H} 2 \mathrm{AX}$ in both categories of cells, demonstrate the clastogenic potential of L-AA on the HeLa cells, especially during longer exposure $(48 \mathrm{~h})$. However, whereas the clastogenicity of L-AA was able to cause killing in $\mathrm{CIN}_{\mathrm{lo}}$ cells, it was not found to reduce the viability of $\mathrm{CIN}_{\mathrm{hi}}$ cells. The differential effect on 2 categories of cells may help to explain the contradictory results of the studies trying to investigate the effect of vitamin $C$ on cancer cells.

A complex effect was observed on the cell cycle upon treatment with L-AA. Colchicine, being a mitotic spindle inhibitor, resulted in cell cycle arrest in the G2/M phase. Treatment of these cells with L-AA resulted in the distribution of the cells to the $\mathrm{S}$ and $\mathrm{G} 2 / \mathrm{M}$ phases. Also, in these $\mathrm{CIN}_{\text {hi }}$ cells, the S-phase fraction (SPF) was seen to increase. Treatment with L-AA alone showed complex effects with a mild increase in SPF. Previous studies have also highlighted that the irregular cell cycle kinetics observed with L-AA, with cell cycle arrest in the S, G2M and G0/G1 phases, is dependent on the cell line being studied, and that this inhibition of cell division promoted necrosis of the malignant cells. In those studies, L-AA was found to act by regulating the activity of various molecules related to cell cycles, such as Cdc25C, Chk2-p53-p21 ${ }^{\text {waf1/cip1 }}$, etc. ${ }^{13-16}$

The apoptosis assay carried out in our study did not demonstrate much increase in the population of the apoptotic cells, thereby indicating that L-AA may be causing cell death by mechanisms other than apoptosis. Previous studies have also reported different mechanisms of cell death caused by vitamin C like autoschizis (cell splitting), apoptosis progressing to pyknosis/necrosis on prolonged treatment, etc. ${ }^{15-18}$ The exact modes of cell death involved in vitamin $C$ induced cytotoxicity, therefore, remain to be investigated.

Thus, our study suggests that treatment with L-AA may have different effects on $\mathrm{CIN}_{\mathrm{hi}}$ and $\mathrm{CIN}_{\text {lo }}$ cancer cells. The genotoxic and cytotoxic effect of high-dose L-AA on $\mathrm{CIN}_{\mathrm{lo}}$, but not on $\mathrm{CIN}_{\mathrm{hi}} \mathrm{HeLa}$ cells, may be due to a difference in the oxidative status of these cell types. However, it needs to be confirmed in future studies. Moreover, our results also point toward the clastogenic potential of L-AA, as indicated by the increased MN score and increased expression of DNA damage response marker $\gamma \mathrm{H} 2 \mathrm{AX}$. 
However, the preliminary data obtained from the present study needs to be confirmed, using more robust studies, employing small interfering RNA (siRNA)-based methods for the induction of CIN and molecular techniques, like fluorescent in situ hybridization, for the measurement of CIN.

\section{References}

1. van Wely KM, Martinez CA. Linking stem cells to chromosomal instability. Oncoimmunol. 2012;1(2):195-200.

2. Cameron E, Pauling L. Supplemental ascorbate in the supportive treatment of cancer: Prolongation of survival times in terminal human cancer. Proc Natl Acad Sci U S A. 1976;73(10):3685-3689.

3. Hoffer LJ, Robitaille L, Zakarian R, et al. High-dose intravenous vitamin C combined with cytotoxic chemotherapy in patients with advanced cancer: A phase I-II clinical trial. PLOS ONE. 2015;10(4): e0120228. doi: 10.1371/journal.pone.0120228

4. Doskey CM, Buranasudja V, Wagner BA, et al. Tumor cells have decreased ability to metabolize $\mathrm{H}_{2} \mathrm{O}_{2}$ : Implications for pharmacological ascorbate in cancer therapy. Redox Biol. 2016;10:274-284.

5. Yun J, Mullarky E, Lu C, et al. Vitamin C selectively kills KRAS and BRAF mutant colorectal cancer cells by targeting GAPDH. Science. 2015;350(6266):1391-1396.

6. Bonuccelli G, De Francesco EM, de Boer R, Tanowitz HB, Lisanti MP. NADH autofluorescence, a new metabolic biomarker for cancer stem cells: Identification of vitamin C and CAPE as natural products targeting "stemness". Oncotarget. 2017; 8(13):20667-20678. doi: 10.18632/oncotarget.1540

7. Ma Y, Chapman J, Levine M, Polireddy K, Drisko J, Chen Q. Highdose parenteral ascorbate enhanced chemosensitivity of ovarian cancer and reduced toxicity of chemotherapy. Sci Transl Med. 2014;6(222):222ra18. doi: 10.1126/scitransImed.3007154

8. Kundu LM, Ray S. Mitotic abnormalities and micronuclei inducing potentials of colchicine and leaf aqueous extracts of Clerodendrum viscosum Vent. in Allium cepa root apical meristem cells. International Journal of Cytology, Cytosystematics and Cytogenetics. 2016;70:7-14.
9. Nefic $\mathrm{H}$. The genotoxicity of vitamin $\mathrm{C}$ in vitro. Bosn J Basic Med Sci. 2008;8(2):142-146.

10. Madhuri K, Vani K, Syed R, Alshatwi AA. Role of ascorbic acid as an antioxidant in gastric cancer patients in South Indian population. Int J Pharm Pharm Sci. 2011;3:179-181.

11. Azqueta A, Costa S, Lorenzo Y, Bastani NE, Collins AR. Vitamin C in cultured human (HeLa) cells: Lack of effect on DNA protection and repair. Nutrients. 2013;5(4):1200-1217.

12. Weaver BA, Silk AD, Montagna C, Verdier-Pinard P, Cleveland DW. Aneuploidy acts both oncogenically and as a tumor suppressor. Cancer Cell. 2013;11(1):25-36.

13. Thomas CG, Vezyraki PE, Kalfakakou VP, Evangelou AM. Vitamin C transiently arrests cancer cell cycle progression in S phase and $\mathrm{G} 2 / \mathrm{M}$ boundary by modulating the kinetics of activation and the subcellular localization of $\mathrm{Cdc} 25 \mathrm{C}$ phosphatase. J Cell Physiol. 2005;205(2):310-318.

14. Guerriero E, Sorice A, Capone F, et al. Vitamin C effect on mitoxantrone-induced cytotoxicity in human breast cancer cell lines. PLOS ONE. 2014;9(12):e115287. doi: 10.1371/journal.pone.0115287

15. Hahm E, Jin DH, Kang JS, et al. The molecular mechanisms of vitamin Con cell cycle regulation in B16F10 murine melanoma.J Cell Biochem. 2007;102(4):1002-1010.

16. Sajadian SO, Tripura C, Samani FS, et al. Vitamin C enhances epigenetic modifications induced by 5 -azacytidine and cell cycle arrest in the hepatocellular carcinoma cell lines HLE and Huh7. Clin Epigenetics. 2016;8:46. doi: 10.1186/s13148-016-0213-6

17. Verrax J, Cadrobbi J, Delvaux M, et al. The association of vitamins $C$ and K3 kills cancer cells mainly by autoschizis, a novel form of cell death: Basis for their potential use as coadjuvants in anticancer therapy. Eur J Med Chem. 2003;38(5):451-457.

18. Chen Q, Espey MG, Krishna MC, et al. Pharmacologic ascorbic acid concentrations selectively kill cancer cells: Action as a pro-drug to deliver hydrogen peroxide to tissues. Proc Natl Acad Sci U S A. 2005;102(38):13604-13609. 